\title{
Extra Virgin Olive Oil and Cardiovascular Diseases: Benefits for Human Health
}

\author{
Cristina Nocella ${ }^{1}$, Vittoria Cammisotto ${ }^{2}$, Luca Fianchini ${ }^{2}$, Alessandra D’Amico ${ }^{1}$, Marta Novo ${ }^{2}$, \\ Valentina Castellani ${ }^{2}$, Lucia Stefanini ${ }^{2}$, Francesco Violi ${ }^{2}$ and Roberto Carnevale ${ }^{1, *}$
}

\author{
${ }^{1}$ Department of Medical-Surgical Sciences and Biotechnologies, Sapienza University of Rome, Rome, Italy; ${ }^{2}$ Department \\ of Internal Medicine and Medical Specialties, Sapienza University of Rome, Rome, Italy
}

\begin{abstract}
Background and Objective: The cardioprotective properties of Mediterranean Diet were demonstrated for the first time from the Seven Country Study. In the last few decades, numerous epidemiological studies, as well as intervention trial, confirmed this observation, pointing out the close relationship between the Mediterranean diet and cardiovascular diseases. In this context, extra virgin olive oil (EVOO), the most representative component of this diet, seems to be relevant in lowering the incidence of cardiovascular events, including myocardial infarction and stroke. From a chemical point of view, $98-99 \%$ of the total weight of EVOO is represented by fatty acids, especially monounsaturated fatty acids such as oleic acid. Tocopherols, polyphenols and other minor constituents represent the remaining $1-2 \%$. All these components may potentially contribute to "health maintenance" with their beneficial effects by EVOOO.
\end{abstract}

\section{A R T I C L E H I S T O R Y}

Received: June 02, 2017

Revised: June 16, 2017

Accepted: October 30, 2017

DOI:

10.2174/1871530317666171114121533

Methods: Studies that examined the effect of EVOO supplementation in healthy subjects and in individuals at cardiovascular risk were included.

Conclusion: The studies analyzed demonstrated the role of EVOO as anti-inflammatory, antioxidant and vasodilatory nutrient that may contribute to lower the atherosclerotic burden.

Keywords: Antioxidant, anti-atherosclerotic nutrient, endothelial dysfunction, extra virgin olive oil, cardiovascular disease, nutraceutical.

\section{INTRODUCTION}

Despite the new pharmaceutical therapies and the progress in the field of cardiovascular medicine, cardiovascular diseases (CVDs) represent the first cause of death in the Western world. More people die annually from CVDs than from any other cause. Significant changes in lifestyle, such as unhealthy diet, contribute to increased CVDs; therefore addressing behavioural risk factors can prevent most of them. In fact, many risk factors associated with the aetiology of cardiovascular disease are amenable to a nutraceutical approach, which refers to biologically active food-derived substances. This represents a powerful tool for maintaining health, counteracting the progressive incidence of CVDs.

The Mediterranean diet, the golden standard for healthy nutrition, is characterized by great intake of nutrients rich in polyphenols and is associated with reduced risk of cardiovascular events [1]. Among these nutrients, olive oil is universally recognized as a symbol of the Mediterranean diet: it represents the primary source of fat and has been associated

*Address correspondence to this author at the Department of MedicalSurgical Medical-Surgical Sciences and Biotechnologies, Sapienza University of Rome, Rome, Italy; Tel: +39 0773 1757231; Fax: +39 0773 1757231; E-mail: roberto.carnevale@uniromal.it with a lower incidence of chronic heart diseases [2]. Based on the description and the definition reported in European Union Regulations [3], olive oils are classified, according to their quality, in extra virgin olive oil (EVOO), virgin olive oil (VOO) and ordinary olive oil (OO). EVOO is a virgin olive oil having a maximum free acidity in terms of oleic acid, of $0.8 \mathrm{~g}$ of acid per $100 \mathrm{~g}$ of oil; VOO is a virgin olive oil having a maximum free acidity of $2 \mathrm{~g}$ per $100 \mathrm{~g}$; ordinary olive oil is an olive oil with acidity not more than $3.3 \%$.

Special attention has been given to the compounds found in EVOO. The nutritional and healthy values, as well as the biological properties of EVOO, can be attributed to its bioactive components including monounsaturated fatty acids (MUFAs) and polyunsaturated fatty acids, tocopherols, and polyphenols, in particular bio-phenols, which are the most represented. Among the beneficial properties of EVOO, its antioxidant effects have been intensively studied because of the link between oxidative stress and atherosclerotic diseases [4]. Oxidative stress is implicated in the pathogenesis of several risk factors of atherosclerosis including hypertension, diabetes and metabolic syndrome [4-6]. The aim of this review is to highlight the role of EVOO in the atherosclerosis pathophysiology and its putative beneficial effects in the setting of cardiovascular disease. 


\section{OXIDATIVE STRESS AND CARDIOVASCULAR DISEASES}

Reactive oxygen species (ROS) includes 1) free radical species, that contains unpaired electrons and have strong oxidation ability such as superoxide anion $\left(\mathrm{O}_{2}{ }^{-}\right)$, peroxynitrite (ONOO-), hydroxyl radical ( $\left.\mathrm{HO}^{-}\right)$and 2 ) non-radicals species, such as hydrogen peroxide $\left(\mathrm{H}_{2} \mathrm{O}_{2}\right)$, that is a longerlasting signalling molecule having oxidation ability. A variety of cell types, including vascular smooth muscle cells (VSMCs), endothelial cells, mononuclear cells and platelets, produce ROS using many enzymatic systems including nicotinamide adenine dinucleotide phosphate (NADPH) oxidase, mitochondrial enzymes, uncoupled endothelial nitric oxide synthase (eNOS), and xanthine oxidase (XO). In the vascular system, several antioxidant mechanisms act to contrast ROS generation: superoxide dismutase (SOD), catalase, glutathione peroxidase (GPx), paraoxonase (PONs) and thioredoxin (TRX) peroxidase. SOD rapidly dismutes $\mathrm{O}_{2}{ }^{-}$to $\mathrm{H}_{2} \mathrm{O}_{2}$, and then $\mathrm{H}_{2} \mathrm{O}_{2}$ is eliminated by GPx and converted into water. TRX is present in endothelial cells and VSMC and it can scavenge ROS such as $\mathrm{H} 2 \mathrm{O} 2$ and ONOO-. PON enzymes have peroxidase-like activity and protect against lipoprotein oxidation [7]

The imbalance between the ROS formation and the antioxidant defence capability, in favour of pro-oxidant processes, is defined as oxidative stress. When endothelial cells become susceptible to oxidative stress, the activation of several signalling cascades and redox- sensitive transcriptional factors induces endothelial dysfunction, leading to the development of atherosclerosis (Fig. 1).

\section{OXIDATIVE STRESS AND ENDOTHELIAL DYSFUNCTION}

The vascular endothelium plays a critical role in the pathophysiology of several vascular diseases and disorders. Under basal conditions, the endothelium regulates the traffic of macromolecules, the circulation of cells from blood to tissues and the maintenance of the vessel in a relatively neutral state favouring dilatation over constriction [8]. An enhanced production of ROS and an attenuated antioxidant system would contribute to damage or excessively activate endothelial cells, causing the secretion of vasoconstrictor factors such as Angiotensin II, endothelin-1 (ET1) and norepinephrine [9]. Conversely, ROS induce inactivation of nitric oxide (NO), a potent vasodilator and anti-aggregating molecule [10].

Changes of the endothelial redox state have a profound impact on endothelial NO availability. Endothelial NO production derives from eNOS that utilizes L-arginine in the presence of oxygen, tetrahydrobiopterin $(\mathrm{BH} 4)$, and reduced NADPH to produce NO and L-citrulline [10]. Oxidative stress could affect NO bioavailability by different mechanisms: 1) increased $\mathrm{O} 2$ - reacts rapidly with $\mathrm{NO}$, resulting in the formation of the potent oxidant peroxynitrite (ONOO-) with consequent loss of NO bioactivity; 2) ROS promotes oxidative degradation of the critical eNOS cofactor $\mathrm{BH} 4$ leading to "uncoupling" of the enzyme with reduced $\mathrm{NO}$. and increased $\mathrm{O}_{2}^{-}$production [11].

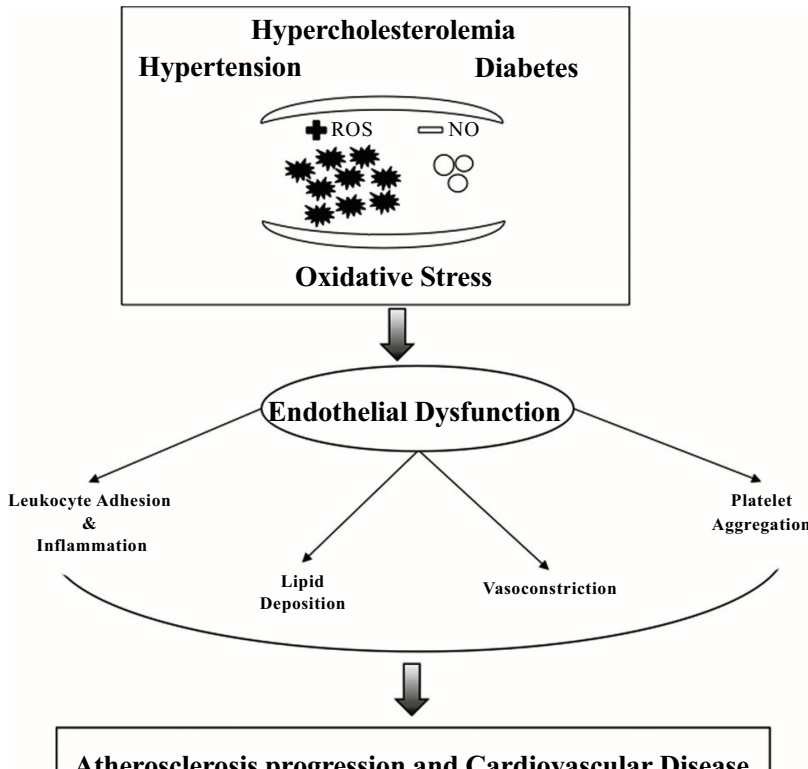

Atherosclerosis progression and Cardiovascular Disease

Fig. (1). Progression of atherosclerosis and cardiovascular disease mediated by oxidative stress and endothelial dysfunction. Traditional risk factors as hypertension, diabetes, and hypercholesterolemia are associated with a decrease in NO bioavailability and increase of radical species and promote oxidative stress and endothelial dysfunction that play an important role atherosclerosis development.

This pathologic state, characterized by compromised endothelial responses, promotes platelet and leukocyte activation and adhesion and increases the permeability of the vessel wall to oxidized lipoproteins and inflammation mediators. The consequent structural damage of the arterial wall determines atherosclerotic plaque formation.

\section{OXIDATIVE STRESS AND ATHEROSCLEROSIS}

ROS play a key role in the atherosclerotic process that is a multistep and multifactorial pathological condition characterized by a plethora of events occurring in the vascular wall, such as endothelial activation, macrophage infiltration and eventually plaque formation [12]. In this context, ROS mediate different signalling pathways that promote vascular inflammation in atherogenesis from the initiation of fatty streak development through lesion progression to ultimate plaque rupture [13]. Increased oxidative stress in vascular cells promotes conversion of low-density lipoprotein LDL to more atherogenic oxidised LDL (ox-LDL). Oxidative modification of LDL cholesterol is the most biologically relevant modification that promotes atherosclerosis and that is responsible for the clinical events resulting from atherosclerosis. Moreover, ox-LDL itself represents a potent stimulus of vascular ROS formation increasing oxidative stress and contributing to the inflammatory state of atherosclerosis [14].

Among different enzymatic pathways that can originate ROS in the vessel wall, NADPH oxidase (Nox) and in particular its isoform Nox2, is a key enzyme in the atherosclerotic process. Nox 2 is expressed in endothelial cells, adventitial fibroblasts, inflammatory cells of developing atheroscle- 
rotic lesions and platelets. The role of Nox2 in atherosclerosis is supported by both humans and animal models [15-17].

\section{INFLAMMATION AND ATHEROSCLEROSIS}

In recent years, chronic inflammation has become recognized as a contributory factor in the development of numerous chronic diseases including CVD and the concept that inflammation plays a role in the initiation and progression of atherosclerosis is now well accepted [18]. There are different inflammatory cell types that play major roles in mediating the inflammatory response that is part of atherosclerosis including T-cells, monocytes, and neutrophils [19]. The inflammatory response begins when lipid and lipoproteins are retained in the artery wall, especially when the lipids are oxidatively modified. These lipids and lipoproteins are taken up by macrophages, dendritic cells, and smooth muscle cells to form foam cells. The production and release of proinflammatory cytokines and chemokines, such as tumour necrosis factor (TNF)- $\alpha$, interferons (IFNs), monocyte chemoattractant protein-1, stromal cell-derived factor-1, macrophage inflammatory protein-1, contribute to further elaborate the inflammatory response in the vessel wall. This pro-inflammatory status within the atherosclerotic lesion, in addition to oxidative stress, enhances atheroprogression [20].

\section{EXTRA-VIRGIN OLIVE OIL (EVOO) AND REGULAR OLIVE OIL (ROO)}

Many epidemiological studies, including randomised controlled trials, show that the intake of olive oil improves cardiovascular health [21]. The dietary intervention trial has demonstrated that an MD enriched with extra virgin olive oil has beneficial effects on blood pressure, glycaemic control in diabetics, endothelial function, oxidative stress and lipid profiles; in addition, it reduces susceptibility of LDL to oxidation and concentrations of inflammatory markers such as C-reactive protein and IL-6 [22].

The benefits of olive oil have been related to its high content of MUFA and its richness in bioactive microcomponents such as polyphenols, abundant in virgin and extra-virgin olive oil but not in ordinary olive oil.

Guasch-Ferré et al., [2] in an observational study found that baseline total olive oil consumption, especially EVOO variety, was associated with a significant reduced risk of cardiovascular events and cardiovascular mortality in a Mediterranean population at high cardiovascular risk. They reported that increases of $10 \mathrm{~g} / \mathrm{d}$ in EVOO intake were associated with a $10 \%$ reduction in the risk of cardiovascular events. On the contrary, consumption of common OO was not significantly associated with cardiovascular morbidity and mortality [2].

The effects of olive oil with EVOO and without regular olive oil (ROO) antioxidant minor compounds were evaluated on the levels of postprandial markers related to thrombogenesis and fibrinolysis, and triglycerides (TG) in healthy subjects. The results obtained highlighted that after 1-week lead-in dietary period, EVOO and ROO did not change fasting plasma levels of $\mathrm{TG}$, tissue factor (TF), fibrinogen, tissue-type plasminogen activator (t-PA) and plasminogen activator inhibitor-1. However, the net incremental area under the curve (AUC) for haemostatic markers was significantly lower after the EVOO meal compared with the ROO meal. This study demonstrated the role of antioxidant minor compounds from EVOO in the regulation of the postprandial haemostatic system and their cardioprotective effects [23]. In a previous study, same authors compared the effects of two diets enriched in olive oils, having the same fatty acid composition but with EVOO and without OO minor compounds, on postprandial accumulation of sICAM-1 and sVCAM-1 in healthy and hyper-triacylglycerolaemic subjects. They demostrated that the minor compounds of EVOO may reduce the release of sICAM-1 and SVCAM-1 after acute intake of a high-fat meal [24].

The comparison between EVOO and ROO was studied to evaluate the improvement of the lipid profile too. RamirezRamirez-Tortosa et al., [25] in a crossover design compared the effects of EVOO and ROO on plasma lipids and lipoprotein composition and LDL oxidation susceptibility in men with peripheral vascular disease. The LDL susceptibility to oxidation was significantly lower after the EVOO consumption than after that of ROO. In addition, total LDL uptake by human macrophages was significantly greater in LDL isolated when the patients consumed ROO rather than EVOO. This data suggests that antioxidants present in EVOO may protect LDL against oxidation more than $\mathrm{OO}$ does in men with peripheral vascular disease [25].

\section{THE EFFECT OF EVOO ON OXIDATIVE STRESS- MEDIATED ENDOTHELIAL DYSFUNCTION AND ATHEROSCLEROSIS}

The Mediterranean diet (MeDiet) is characterized by a high intake of EVOO, nuts, legumes, vegetables, fruit, fish, cereals and moderate wine consumption, with scarce intake of dairy products and red meat [26]. Many intervention studies showed that a Mediterranean dietary pattern, that includes EVOO, is strongly associated with a reduced risk of CVD [27]. Even if the molecular mechanisms exerted by EVOO are not fully understood, the healthy role of EVOO could be referred to its high level of MUFA and several biologically active phenolic compounds known to play important roles in cardiovascular protection [28].

Considering the role of oxidative stress in the pathogenesis of atherosclerosis, a number of studies evaluated the antioxidant effect of EVOO. Long and short-term studies suggested that phenolic compounds are important for the cardiovascular benefits of EVOO and showed an improvement of antioxidant capacity $[29,30]$ and a reduction of F2Isoprostane, ROS production and serum sNOX2-dp [31, 32], a marker of Nox2 activation. Moreover, EVOO supplemented to a Mediterranean lunch is capable of blunting oxidative stress by regulating platelet oxidative stress and endothelial dysfunction, as demonstrated by a reduction in Nox2 activation and soluble E-selectin/VCAM1 release, respectively [31].

Soluble adhesion molecules such as E-selectin and Pselectin, vascular cell adhesion molecule-1 (VCAM-1), and intercellular adhesion molecule-1 (ICAM-1) are predictors for endothelial dysfunction that represents an early marker of atherosclerosis events associated with cardiovascular risk 
factors [33]. If after the short-term intervention with EVOO the comparison between groups reached statistical significance neither for sE-selectin and sP-selectin nor for ICAM-1 [34], Casas et al., [26] after 1 year of intervention with EVOO highlighted a decrease of soluble adhesion molecules such as P-selectin, VCAM-1 and ICAM-1. Moreover, increased flow-mediated dilatation (FMD) [35], internal carotid intima-media thickness and plaque height [36] measurements proved the ability of the MeDiet supplemented with EVOO to improve endothelial function. NO loss or reduction is associated with endothelial dysfunction. Data from long-term (1 year) intervention studies on subjects at high cardiovascular risk show that EVOO consumption is associated with an increase of NO availability [37, 38] and an upregulation of eNOS [37]. Conversely, Sala-Vila et al., [36] demonstrated that EVOO supplementation did not show any significant improvement of artery wall condition.

Ox-LDL is a more potent pro-atherosclerotic factor than native unmodified LDL. ROS are able to begin lipid peroxidation leading to activation of native unmodified LDL and formation of ox-LDL [39]. A decrease of ox-LDL was reported in long-term studies (1 year) in subjects at high cardiovascular risk after the virgin olive oil consumption compared with the control group [40, 41]. In the EUROLIVE study, European participants were enrolled in a crossover study and were randomly assigned to three groups of olive oil differing in their phenolic content (low, medium and high) for three weeks. After olive oil intake, oxidized LDL levels decreased linearly with increasing phenolic content along with changes of other oxidative markers such as a reduction in $\mathrm{C} 18$ hydroxy fatty acid, conjugated dienes formation [42], plasma-F2isoprostanes production [43] and an improvement in the balance between reduced and oxidized glutathione GSH and GSSG [42]. Moreover, olive oil promotes the generation of OxLDL autoantibodies, that have a protective role in atherosclerosis [44], while no changes in OxLDL and conjugated dienes were found [43].

The role of EVOO as anti-atherosclerotic nutrients is also supported by its ability to modulate human expressions of atherosclerosis-related genes in which LDL oxidation is involved. After high polyphenol content (HPC; $366 \mathrm{mg} / \mathrm{kg}$ ) in olive oil interventions $(25 \mathrm{ml} /$ day $)$, a reduction in LDL oxidation and in the expression of proatherogenic and proinflammatory genes related with the CD40/CD40L pathway is observed. This effect led to a reduction in the expression of its downstream products such as vascular endothelial growth factor- $\beta$ and monocyte chemoattractant protein-1, interleukin (IL)-8, and intercellular adhesion molecule-1 (ICAM1) via a decrease in Mitogen-Activated Protein Kinase-1 (MAPK1) activation [45]. The anti-inflammatory effect in the vascular wall may be another important mechanism that helps to explain the link between the EVOO and cardiovascular disease development. Casas R et al., [46] in their recent study evaluated inflammatory markers like high-sensitivity C-reactive protein (hs-CRP), the levels of main cytokines (IL- $1 \beta, 5,6$, $7,8,12$, TNF- $\alpha$, and IFN- $\gamma$ ) and vulnerability plaque marker (IL-10, 13, and 18) levels. They showed an improvement of these parameters in people having high cardiovascular risk long-term adherence, treated with MeDiet supplemented with EVOO, suggesting a delay in atheroma plaque forma- tion [26, 46, 47]. Consumption of a Mediterranean-style diet supplemented with EVOO also in patients with the metabolic syndrome was associated a significant reduction of systemic vascular inflammation markers (IL-6, IL-7, IL18, and hs-CRP) [48]. Different results were reported after a short-term study ( 2 months) on subjects with abdominal obesity and without cardiovascular disease. In this study, the MeDiet supplemented with EVOO showed a beneficial tendency towards the down-regulation of some vascular inflammation markers (CRP and IL-6), however after the intervention, the comparison between groups did not reach statistical significance [34]. The intervention studies are summarized in Table $\mathbf{1}$.

These results compared with long-term studies may suggest that a longer period of dietary intervention may be required to modify concentration of the particular markers. While a significant decrease in inflammatory markers, namely Thromboxane-B2 (TXB2) and Leukotriene-B4, in both long- and short-term studies [30], EVOO supplementation confirmed the antithrombotic and anti-inflammatory effects of EVOO in a postprandial state too [29]. These mechanisms are depicted in Fig. (2).

\section{THE EFFECT OF EVOO ON CARDIOVASCULAR RISK FACTORS}

Several factors, such as blood pressure, serum cholesterol and glucose, contribute to the development of atherosclerosis [59-61].

Atherogenic stimuli like hypertension may activate the inflammatory response through oxidative stress by causing expression of mononuclear leucocyte recruiting mechanisms and may exert oxidative stress directly on the arterial wall and predispose to and accelerate atherosclerosis. The etiology and development of hypertension are related to the imbalance of vasodilation/vasoconstriction molecules released by endothelium, such as NO, a potent relaxing factor, and ET1 a potent vasoconstrictor. Mediterranean diet supplemented with EVOO for 1 year in non-smoking woman with moderate hypertension is able to increase serum NO along with changes in gene expression including 1) The upregulation of eNOS that keeps blood vessels dilated, controls blood pressure, and has numerous other vasoprotective and anti-atherosclerotic effects and 2) The down-regulation of caveolin 2 that binds eNOS resulting in stearic inhibition of the enzyme [37].

In long-term studies on subjects at high cardiovascular risk, after supplemented EVOO MeDiet, the blood pressure values, both systolic and diastolic, are reduced $[35,37,38]$. The same results were recorded in a two-year study ( 2 years) on subjects with metabolic syndrome [48]. The results reported in the studies of Storniolo et al., [37] are very interesting where they showed a decrease in blood pressure values only in the moderate hypertensive group and not in the control group.

Nutritional interventions with EVOO are strong approaches to prevent the onset of a wide range of chronic diseases including type 2 diabetes, obesity, and metabolic syndrome, due to their potential to ameliorate plasma glucose 
Table 1. Extra Virgin Olive Oil (EVOO) effects on cardiovascular disease. The main characteristics and the main results of intervention studies are reported.

\begin{tabular}{|c|c|c|c|c|c|}
\hline Treatment & Dose & $\begin{array}{c}\text { Subjects N } \\
\text { Healthy Status }\end{array}$ & $\begin{array}{l}\text { Study Design, } \\
\text { Duration }\end{array}$ & Markers & References \\
\hline Extra virgin olive oil & $1 \mathrm{~L} /$ week & $\begin{array}{c}7447 \\
\text { High cardiovascular } \\
\text { risk }\end{array}$ & $\begin{array}{l}\text { Parallel, } \\
4.8 \text { year }\end{array}$ & $\begin{array}{c}\text { - central obesity } \downarrow \\
\text { - high fasting glucose } \downarrow\end{array}$ & $\begin{array}{c}\text { Babio et al. } 2014 \\
{[49]}\end{array}$ \\
\hline Extra virgin olive oil & $50 \mathrm{ml}$ & $\begin{array}{l}12 \\
\text { Healthy subjects -Hydrogen } \\
\text { peroxide levels } \uparrow\end{array}$ & $\begin{array}{c}\text { Parallel, } \\
\text { acute }(1-2-6 \mathrm{~h})\end{array}$ & $\begin{array}{c}- \text { - TxB2 } \downarrow \\
-\mathrm{LTB} 4 \downarrow \\
\text { - Antioxidant capacity } \uparrow \\
-\mathrm{H}_{2} \mathrm{O}_{2} \uparrow\end{array}$ & $\begin{array}{c}\text { Bogani et al. } 2017 \\
{[30]}\end{array}$ \\
\hline Extra virgin olive oil & $10 \mathrm{~g}$ & $\begin{array}{c}25 \\
\text { Healthy subjects }\end{array}$ & $\begin{array}{l}\text { Cross-over, } \\
\text { acute }(2 \mathrm{~h}) \\
\text { Postprandial }\end{array}$ & $\begin{array}{l}\text { - ROS production } \downarrow \\
\text { - serum sNOX2-dp } \downarrow \\
\text { - 8-iso-PGF2a-III } \downarrow\end{array}$ & $\begin{array}{l}\text { Carnevale et al. } \\
\quad 2014[31]\end{array}$ \\
\hline $\begin{array}{c}\text { Extra virgin olive oil } \\
\text { (MeDiet+ EVOO) }\end{array}$ & 1 liter/week & $\begin{array}{l}69 \\
\text { High cardiovascular } \\
\text { risk } \\
\end{array}$ & $\begin{array}{r}\text { Parallel, } \\
5 \text { years }\end{array}$ & $\begin{array}{c}- \text { IL-6 } \downarrow \text {, IL-8 } \downarrow \text {, MCP-1 } \downarrow \text {, MIP-1 } \beta \downarrow \\
\text { - IL-1 } 1 \beta \downarrow, \text { IL- } 5 \downarrow, \text { IL-7 } \downarrow \text {, IL-12p70 } \downarrow \text {, IL-18 } \downarrow \text {, TNF- } \alpha \\
\downarrow \text {, IFN- } \gamma \downarrow \text {, GCSF } \downarrow \text {, GMCSF } \downarrow, \text { ENA78 } \downarrow\end{array}$ & $\begin{array}{c}\text { Casas et al. } 2017 \\
{[26]}\end{array}$ \\
\hline $\begin{array}{l}\text { Extra virgin olive oil } \\
\text { (MeDiet+ EVOO) }\end{array}$ & $50 \mathrm{ml} / \mathrm{d}$ & $\begin{array}{l}165 \\
\text { High cardiovascular } \\
\text { risk }\end{array}$ & $\begin{array}{l}\text { Parallel, } \\
3-5 \text { year }\end{array}$ & $\begin{array}{c}\text { - CRP } \downarrow \\
\text { - Interleukin-6, } \downarrow \\
\text { - TNF- } \alpha \downarrow \\
\text { - HDL-cholesterol } \uparrow \\
\text { - Total cholesterol } \downarrow \\
\text { - LDL-cholesterol } \downarrow \\
\text { - Triglyceride } \downarrow \\
\text { - Blood pressure } \downarrow\end{array}$ & $\begin{array}{c}\text { Casas et al. } 2016 \\
{[47]}\end{array}$ \\
\hline $\begin{array}{c}\text { Extra virgin olive oil } \\
(\text { MeDiet }+ \text { EVOO })\end{array}$ & $50 \mathrm{~mL} / \mathrm{d}$ & $\begin{array}{l}164 \\
\text { High cardiovascular } \\
\text { risk }\end{array}$ & $\begin{array}{l}\text { Parallel, } \\
1 \text { year }\end{array}$ & $\begin{array}{c}\text { - [sVCAM- } 1] \downarrow \text { [sICAM- } 1] \downarrow,[\text { sP-selectin }] \downarrow \\
\text { - CRP } \downarrow, \text { IL-6 } \downarrow, \text { IL-18/IL-10 } \downarrow\end{array}$ & $\begin{array}{c}\text { Casas et al. } 2014 \\
{[46]}\end{array}$ \\
\hline Olive oil & $25 \mathrm{ml} / \mathrm{d}$ & $\begin{array}{c}60 \\
\text { Healthy subjects }\end{array}$ & $\begin{array}{l}\text { Cross over, } \\
3 \text { weeks }\end{array}$ & - Plasma OxLDL autoantibodies $\uparrow$ & $\begin{array}{l}\text { Castaner et al. } \\
2011[44]\end{array}$ \\
\hline Olive oil & $25 \mathrm{ml} / \mathrm{d}$ & $\begin{array}{c}200 \\
\text { Healthy subjects }\end{array}$ & $\begin{array}{l}\text { Cross over, } \\
3 \text { weeks }\end{array}$ & $\begin{array}{c}\text { - HDL cholesterol } \uparrow \\
\text { - Total cholesterol/HDL-C } \downarrow \\
\text { - LDL-C/HDL-C } \downarrow \\
\text { - Triglycerides } \downarrow \\
\text { - Conjugated dienes } \downarrow \text {, hydroxyl fatty acid } \downarrow \text {, oxLDL } \downarrow\end{array}$ & $\begin{array}{c}\text { Covas et al. } 2006 \\
{[42]}\end{array}$ \\
\hline Extra virgin olive oil & $25 \mathrm{ml} / \mathrm{d}$ & $\begin{array}{c}60 \\
\text { Healthy subjects }\end{array}$ & $\begin{array}{l}\text { Parallel, } \\
3 \text { weeks }\end{array}$ & $\begin{array}{c}\text { - PON1 } \downarrow \\
\text { - Conjugated dienes } \downarrow\end{array}$ & $\begin{array}{c}\text { Cherki et al. } 2005 \\
{[50]}\end{array}$ \\
\hline Olive oil & $25 \mathrm{ml} / \mathrm{d}$ & $\begin{array}{c}60 \\
\text { Healthy subjects }\end{array}$ & $\begin{array}{l}\text { Cross over, } \\
3 \text { weeks }\end{array}$ & $\begin{array}{c}\text { - Cholesterol } \leftrightarrow \\
\text { - LDL cholesterol } \leftrightarrow \\
\text { - Triacylglycerols } \leftrightarrow \\
\text { - HDL cholesterol } \uparrow \\
\text { - Glucose } \uparrow \\
\text { - OxLDL } \leftrightarrow \\
\text { - Conjugated dienes } \leftrightarrow \\
\text { - Plasma Isoprostanes } \downarrow\end{array}$ & $\begin{array}{c}\text { Cicero et al. } 2008 \\
{[43]}\end{array}$ \\
\hline $\begin{array}{r}\text { Mediterranean Diet } \\
(\text { MeDiet+ EVOO) }\end{array}$ & $14.8 \mathrm{~mL} / \mathrm{d}$ & $\begin{array}{c}137 \\
\text { Healthy subjects }\end{array}$ & $\begin{array}{l}\text { Parallel, } \\
6 \text { months }\end{array}$ & $\begin{array}{c}\text { - systolic blood pressure } \downarrow \\
\text { - FMD } \uparrow\end{array}$ & $\begin{array}{c}\text { Davis et al. } 2017 \\
{[35]}\end{array}$ \\
\hline $\begin{array}{c}\text { Olive oil } \\
(\text { MeDiet }+ \text { OO })\end{array}$ & $8 \mathrm{~g} / \mathrm{d}$ & $\begin{array}{c}180 \\
\text { Metabolic syndrome }\end{array}$ & $\begin{array}{l}\text { Parallel, } \\
2 \text { years }\end{array}$ & $\begin{array}{c}\text { - Body weight } \downarrow \text {, body mass index } \downarrow \text {, } \\
\text { waist circumference } \downarrow \\
\text { - Endothelial function score } \uparrow \\
\text { - Blood pressure } \downarrow \\
\text { - Blood glucose and insulin, } \downarrow \\
\text { - Total cholesterol } \downarrow \\
\text { - triglycerides } \downarrow \\
\text { - HDL } \uparrow \\
\text { - IL-6 } \downarrow \text {, IL-7 } \downarrow \text {, IL-18 } \downarrow \text {, hs-CRP } \downarrow\end{array}$ & $\begin{array}{l}\text { Esposito et al. } \\
2004[48]\end{array}$ \\
\hline
\end{tabular}

Table (1) contd.... 


\begin{tabular}{|c|c|c|c|c|c|}
\hline Treatment & Dose & $\begin{array}{c}\text { Subjects N } \\
\text { Healthy Status }\end{array}$ & $\begin{array}{l}\text { Study Design, } \\
\text { Duration }\end{array}$ & Markers & References \\
\hline Extra virgin olive oil & $25 \mathrm{ml} / \mathrm{d}$ & $\begin{array}{l}3985 \\
\text { High cardiovascular } \\
\text { risk }\end{array}$ & $\begin{array}{l}\text { Parallel, } \\
5 \text { year }\end{array}$ & $\begin{array}{c}\text { - Bodyweight } \downarrow \\
\text { - Waist circumference } \downarrow\end{array}$ & $\begin{array}{c}\text { Estruch et al. } 2016 \\
{[51]}\end{array}$ \\
\hline Extra virgin olive oil & $25 \mathrm{~g}$ & $\begin{array}{c}183 \\
\text { Obese }\end{array}$ & $\begin{array}{l}\text { Acute- } \\
\text { Postprandial } \\
3,5 \mathrm{~h}\end{array}$ & $\begin{array}{l}\text { - Insuline } \downarrow \\
\text { - C-peptide } \downarrow\end{array}$ & $\begin{array}{l}\text { Farnetti et al. } 2013 \\
\text { [52] }\end{array}$ \\
\hline Virgin olive oil & $5 \mathrm{~L} /$ month & $\begin{array}{c}930 \\
\text { High cardiovascular risk }\end{array}$ & $\begin{array}{c}\text { Parallel, } \\
1 \text { year }\end{array}$ & - ox-LDL $\downarrow$ & $\begin{array}{c}\text { Fitó et al. } 2014 \\
{[41]}\end{array}$ \\
\hline Virgin olive oil & $1 \mathrm{~L} /$ week & $\begin{array}{l}210 \\
\text { High cardiovascular } \\
\text { risk }\end{array}$ & $\begin{array}{l}\text { Parallel, } \\
1 \text { year }\end{array}$ & $\begin{array}{c}\text { - LDL resistance against oxidation } \uparrow \\
\text { - ox-LDL } \downarrow\end{array}$ & $\begin{array}{c}\text { Hernáez et al. } \\
2017[40]\end{array}$ \\
\hline Virgin olive oil & $1 \mathrm{~L} /$ week & $\begin{array}{l}296 \\
\text { High cardiovascular } \\
\text { risk }\end{array}$ & $\begin{array}{l}\text { Parallel, } \\
1 \text { year }\end{array}$ & - HDL oxidative status and composition $\uparrow$ & $\begin{array}{l}\text { Hernáez et al. } \\
2017[53]\end{array}$ \\
\hline $\begin{array}{c}\text { Extra virgin olive oil } \\
\text { and Corn oil }\end{array}$ & $54 \mathrm{~g} / \mathrm{d}$ & $\begin{array}{c}54 \\
\text { Healthy subjects }\end{array}$ & $\begin{array}{l}\text { Crossover, } \\
21 \text { days }\end{array}$ & $\begin{array}{c}-\mathrm{HDL} \uparrow, \mathrm{VLDL} \uparrow \\
-\mathrm{LDL} \downarrow \\
-\mathrm{APO}-\mathrm{B} \mathrm{E} \uparrow, \mathrm{APO}-\mathrm{A} 1 \uparrow\end{array}$ & $\begin{array}{c}\text { Maki et al. } 2017 \\
{[54]}\end{array}$ \\
\hline Extra virgin olive oil & 1L/week & $\begin{array}{l}\text { High cardiovascular } \\
\text { risk }\end{array}$ & $\begin{array}{l}\text { Parallel, } \\
1 \text { year }\end{array}$ & $\begin{array}{c}\text { - Systolic/diastolic blood pressure } \downarrow \\
\text { - Plasma NO } \uparrow\end{array}$ & $\begin{array}{l}\text { Medina-Remón } \\
\text { et al. } 2015 \text { [38] }\end{array}$ \\
\hline Extra virgin olive oil & 1L/week & $\begin{array}{c}110 \\
\text { Metabolic syndrome }\end{array}$ & $\begin{array}{l}\text { Parallel, } \\
1,5 \text { years }\end{array}$ & $\begin{array}{c}\text { - Urine levels of F2-Isoprostane } \downarrow \\
\text { - DNA damage base (8-oxo-7,8- dihydro-20- } \\
\text { deoxyguanosine;8-oxo-dG) } \downarrow\end{array}$ & $\begin{array}{l}\text { Mitjavila et al. } \\
2013[32]\end{array}$ \\
\hline Extra virgin olive oil & $45 \mathrm{ml} / \mathrm{d}$ & $\begin{array}{c}90 \\
\text { Abdominal obesity }\end{array}$ & $\begin{array}{l}\text { Parallel, } \\
2 \text { months }\end{array}$ & $\begin{array}{c}\text { - CRP, IL-6 } \leftrightarrow \\
\text { - sP-selectin, sE-selectin } \leftrightarrow \\
\text { - ICAM-1 } \leftrightarrow\end{array}$ & $\begin{array}{c}\text { Rallidis et al. } 2017 \\
\text { [34] }\end{array}$ \\
\hline Extra virgin olive oil & 1L/week & $\begin{array}{c}2866 \\
\text { High cardiovascular risk }\end{array}$ & $\begin{array}{l}\text { Parallel, } \\
1 \text { year }\end{array}$ & $\begin{array}{l}\text { - Glycemic index } \downarrow \\
\text { - Glycemic load } \downarrow\end{array}$ & $\begin{array}{l}\text { Rodríguez-Rejón } \\
\text { et al. } 2014 \text { [55] }\end{array}$ \\
\hline Extra virgin olive oil & $30 \mathrm{~g} / \mathrm{d}$ & $\begin{array}{l}175 \\
\text { High carotid atherosclerotic } \\
\text { burden }\end{array}$ & $\begin{array}{l}\text { Parallel, } \\
\text { 2,4 years }\end{array}$ & $\begin{array}{l}\text { - internal carotid intima-media } \\
\text { thickness } \leftrightarrow \\
\text { - plaque height } \leftrightarrow\end{array}$ & $\begin{array}{c}\text { Sala-Vila et al. } \\
2014[36]\end{array}$ \\
\hline Extra virgin olive oil & & $\begin{array}{c}60 \\
\text { Moderate hypertension }\end{array}$ & $\begin{array}{l}\text { Parallel } \\
1 \text { year }\end{array}$ & $\begin{array}{c}\text { - Serum NO } \uparrow \\
\text { - Blood pressure } \downarrow\end{array}$ & $\begin{array}{c}\text { Storniolo et al. } \\
2016[37]\end{array}$ \\
\hline Extra virgin olive oil & 1L/week & $\begin{array}{c}7158 \\
\text { High cardiovascular risk }\end{array}$ & $\begin{array}{l}\text { Parallel, } \\
\text { 4,8 years }\end{array}$ & $\begin{array}{l}\text { - Systolic blood pressure } \leftrightarrow \\
\text { - Diastolic blood pressure } \downarrow\end{array}$ & $\begin{array}{c}\text { Toledo et al. } 2013 \\
{[56]}\end{array}$ \\
\hline Extra virgin olive oil & $10 \mathrm{~g}$ & $\begin{array}{c}25 \\
\text { Healthy subjects }\end{array}$ & $\begin{array}{l}\text { Cross-over, } \\
\text { acute }(2 \mathrm{~h}) \\
\text { Postprandial }\end{array}$ & $\begin{array}{c}\text { - Blood glucose } \downarrow \\
\text { - DPP-4 protein and activity } \downarrow \\
\text { - LDL-C } \downarrow \text {, ox-LDL } \downarrow \\
\text { - insulin } \uparrow, \text { GLP- } 1 \uparrow, \text { GIP } \uparrow\end{array}$ & $\begin{array}{l}\text { Violi et al. } 2015 \\
\text { [57] }\end{array}$ \\
\hline Extra virgin olive oil & $40 \mathrm{ml} / \mathrm{d}$ & $\begin{array}{c}22 \\
\text { Mild Dyslipidemia }\end{array}$ & $\begin{array}{l}\text { Crossover, } \\
4 \text { weeks }\end{array}$ & $\begin{array}{c}-\mathrm{TBX} 2 \downarrow \\
-8 \text {-iso-PGF2a } \downarrow \\
\text { - Antioxidant capacity } \uparrow\end{array}$ & $\begin{array}{c}\text { Visioli et al. } 2005 \\
{[30]}\end{array}$ \\
\hline $\begin{array}{l}\text { Extra virgin olive oil } \\
\text { (MeDiet + EVOO })\end{array}$ & $1 \mathrm{~L} /$ week & $\begin{array}{l}231 \\
\text { High cardiovascular } \\
\text { risk }\end{array}$ & $\begin{array}{l}\text { Parallel, } \\
1 \text { year }\end{array}$ & - Plasma tryptophan $\downarrow$ & Yu et al. 2017 [58] \\
\hline
\end{tabular}




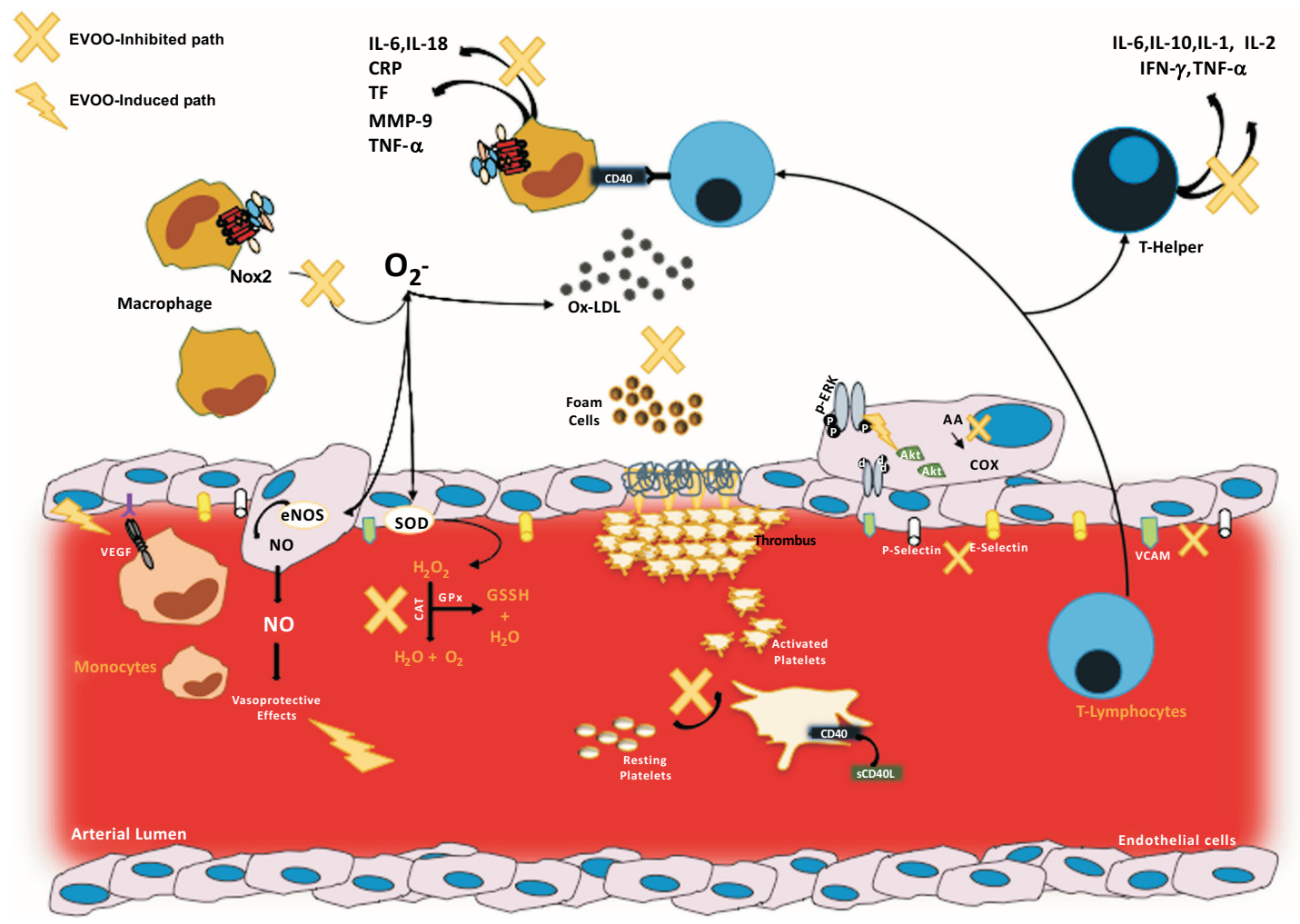

Fig. (2). The role of EVOO in the atherosclerosis pathophysiology. EVOO shows a positive effect on several aspects of cardiovascular disease through its antioxidant, anti-inflammatory and anti-platelet aggregation properties. EVOO is a potent antioxidant that may reduce intracellular ROS production. It may also enhance SOD activity, hence decreasing O2 levels. Moreover, is able to reduce lipid peroxidation and scavenge intracellular ROS and free NO, reducing the formation of OONO. EVOO explicate its anti-inflammatory activity modulating the levels of adhesion molecules and eicosanoids, the expression of inflammatory cytokines and the expression of COX.

and lipids. Changes of glycaemic and lipid profile might have an effect on cardiovascular disease by promoting or aggravating the atherosclerotic process. MeDiet supplemented with EVOO has a beneficial effect on the postprandial metabolic profile by decreasing blood glucose, LDL-C and ox-LDL and increasing insulin levels in healthy subjects [57]. Furthermore, $10 \mathrm{~g}$ of EVOO supplemented to a Mediterranean lunch are able to improve post-prandial glycaemic profile in patients with impaired fasting glucose. The mechanisms accounting for the positive effect of EVOO are related to incretins up-regulation, as EVOO reduces dipeptidyl peptidase-4 activity with consequent increase in glucagon-like peptide-1 concentration which regulates postprandial glycaemia by up-regulating insulin secretion [62].

Hypercholesterolemia is another risk factor for CVD. MeDiet, thanks to its components, has been associated with a reduction in atherogenic cholesterol LDL-C and non-highdensity lipoprotein cholesterol (non-HDL-C) levels [63]. Hernáez et al., [40] in their study showed that 1 year of intervention with a MeDiet, especially when enriched with virgin olive oil, improves several HDL functions such as cholesterol efflux capacity, cholesterol metabolism, antioxidant/anti-inflammatory properties, and vasodilatory capacity, in individuals at high cardiovascular risk. Similarly, Covas et al., [42] found that after consuming phenolic olive oils, HDL-C increased whereas TC/HDL-C ratio decreased with a decrease in LDL-C/HDL-C ratio and triglycerides.
Changes in glycaemic and lipid profile were observed also in patients with the metabolic syndrome. After 2 years, patients in the intervention group (MeDiet supplemented with EVOO) had significant decreases in the levels of glucose, insulin, total cholesterol, and triglycerides and a significant increase in the levels of HDL, all of which were greater than the control group. These data suggest that a Mediterranean-style diet is a possible strategy for the treatment of metabolic syndrome and to reduce the associated cardiovascular risk [48].

In short-term intervention studies, the intake of EVOO does not improve lipidic profile. In fact, in crossover-study of 21 days on 54 healthy subjects, the total cholesterol, LDLC, VLDL-C, APOB, APOA and LDL particle concentrations were improved by corn oil to a greater extent compared with EVOO intake [54].

\section{CONCLUSION}

The data reported here indicate that EVOO intake is associated with a beneficial impact on CVDs. Interventional studies are consistent with these beneficial effects, as supported by the ability of EVOO to prevent or reduce the inflammatory processes associated with chronic-degenerative diseases, such as cardiovascular-cerebral diseases and cancer. The implications and the perspectives of the intake of EVOO are evident considering its role in modulating post- 
prandial hyperglycaemia and hyperlipidaemia and in particular their impact on vascular diseases. Indeed, in the onset of diabetes, EVOO supplementation provides an improvement of post-prandial glucose and lipid profile; this effect represents a new mechanism supporting the role of EVOO as an anti-atherosclerotic nutrient. The intake of EVOO, in conclusion, represents a simple but effective nutritional approach to modulate the deleterious effect of different cardiovascular risk factors, such as oxidative stress, inflammation, postprandial hyperglycaemia and hyperlipidaemia, on the vascular system.

\section{LIST OF ABBREVIATIONS}

\begin{tabular}{|c|c|c|}
\hline AUC & $=$ & Area under the curve \\
\hline $\mathrm{BH} 4$ & $=$ & Tetrahydrobiopterin \\
\hline CVDs & $=$ & Cardiovascular diseases \\
\hline eNOS & $=$ & Endothelial nitric oxide synthase \\
\hline ET1 & $=$ & Endothelin-1 \\
\hline EVOO & $=$ & Extra virgin olive oil \\
\hline FMD & $=$ & Flow-mediated dilatation \\
\hline GLP1 & $=$ & Glucagon-like peptide-1 \\
\hline GPx & $=$ & Glutathione peroxidase \\
\hline HDL & $=$ & High-density lipoprotein \\
\hline $\mathrm{HO}^{-}$ & $=$ & Hydroxyl radical \\
\hline $\mathrm{H}_{2} \mathrm{O}_{2}$ & $=$ & Hydrogen peroxide \\
\hline hs-CRP & $=$ & High-sensitivity C-reactive protein \\
\hline ICAM-1 & $=$ & Intercellular adhesion molecule-1 \\
\hline IFN- $\gamma$ & $=$ & Interferon gamma \\
\hline IL & $=$ & Interleukin \\
\hline $\mathrm{LDL}$ & $=$ & Low-density lipoprotein \\
\hline MAPK1 & $=$ & Mitogen-activated protein kinase- 1 \\
\hline MeDiet & $=$ & Mediterranean diet \\
\hline MUFAs & $=$ & Monounsaturated fatty acids \\
\hline NADPH & $=$ & $\begin{array}{l}\text { Nicotinamide adenine dinucleotide phos- } \\
\text { phate }\end{array}$ \\
\hline NO & $=$ & Nitric oxide \\
\hline Nox & $=$ & NADPH oxidase \\
\hline $\mathrm{O}_{2}^{-}$ & $=$ & Superoxide anion \\
\hline $\mathrm{ONOO}^{-}$ & $=$ & Peroxynitrite \\
\hline ox-LDL & $=$ & Oxidised low-density lipoprotein \\
\hline PONs & $=$ & Paraoxonase \\
\hline ROO & $=$ & Regular olive oil \\
\hline ROS & $=$ & Reactive oxygen species \\
\hline SOD & $=$ & Superoxide dismutase \\
\hline $\mathrm{TF}$ & $=$ & Tissue factor \\
\hline TRX & $=$ & Thioredoxin \\
\hline
\end{tabular}

$\begin{array}{lll}\text { TG } & = & \text { Triglyceride } \\ \text { TNF- } \alpha & = & \text { Tumor necrosis factor } \\ \text { t-PA } & = & \text { Tissue plasminogen activator } \\ \text { TXB2 } & = & \text { Thromboxane-B2 } \\ \text { VCAM-1 } & = & \text { Vascular adhesion molecule-1 } \\ \text { VSMCs } & = & \text { Vascular smooth muscle cells } \\ \text { XO } & = & \text { Xanthine oxidase }\end{array}$

\section{CONSENT FOR PUBLICATION}

Not applicable.

\section{CONFLICT OF INTEREST}

The authors declare no conflict of interest, financial or otherwise.

\section{ACKNOWLEDGEMENTS}

Cristina Nocella and Vittoria Cammisotto equally contributed to this work.

\section{REFERENCES}

[1] Gardener, H.; Wright, C.B.; Gu, Y.; Demmer, R.T.; Boden-Albala, B.; Elkind, M.S.V; Sacco, R.L.; Scarmeas, N. Mediterranean-Style Diet and Risk of Ischemic Stroke, Myocardial Infarction, and Vascular Death: The Northern Manhattan Study. Am. J. Clin. Nutr., 2011, 94, 1458-1464.

[2] Guasch-Ferré, M.; Hu, F.B.; Martínez-González, M.A.; Fitó, M.; Bulló, M.; Estruch, R.; Ros, E.; Corella, D.; Recondo, J.; GómezGracia, E.; Fiol, M.; Lapetra, J.; Serra-Majem, L.; Muñoz, M.A.; Pintó, X.; Lamuela-Raventós, R.M.; Basora, J.; Buil-Cosiales, P.; Sorlí, J.V; Ruiz-Gutiérrez, V.; Martínez, J.A.; Salas-Salvadó, J. Olive Oil Intake and Risk of Cardiovascular Disease and Mortality in the PREDIMED Study. BMC Med., 2014, 12, 78.

[3] Regulation (EU) No 1308/2013. 2014, 189. Available from: http://eur-lex.europa.eu/legal-

content/IT/TXT/?uri=celex:32013R1308 [Accessed October 20, 2017].

[4] Hajjar, D.P.; Gotto, A.M. Biological Relevance of Inflammation and Oxidative Stress in the Pathogenesis of Arterial Diseases. Am. J. Pathol., 2013, 182, 1474-1481.

[5] Rodrigo, R.; González, J.; Paoletto, F. The Role of Oxidative Stress in the Pathophysiology of Hypertension. Hypertens. Res., 2011, 34, 431-440.

[6] Whaley-Connell, A.; McCullough, P.A.; Sowers, J.R. The Role of Oxidative Stress in the Metabolic Syndrome. Rev. Cardiovasc. Med., 2011, 12, 21-29.

[7] Aviram, M.; Rosenblat, M.; Bisgaier, C.L.; Newton, R.S.; PrimoParmo, S.L.; La Du, B.N. Paraoxonase Inhibits High-Density Lipoprotein Oxidation and Preserves Its Functions. A Possible Peroxidative Role for Paraoxonase. J. Clin. Invest., 1998, 101, 1581-1590.

[8] Pearson, J.D. Normal Endothelial Cell Function. Lupus, 2000, 9 , 183-188.

[9] Arakawa, K.; Urata, H. Hypothesis Regarding the Pathophysiological Role of Alternative Pathways of Angiotensin II Formation in Atherosclerosis. Hypertension, 2000, 36, 638-641.

[10] Förstermann, U.; Sessa, W.C. Nitric Oxide Synthases: Regulation and Function. Eur. Heart J., 2012, 33, 829-837, 837a-837d.

[11] Landmesser, U.; Dikalov, S.; Price, S.R.; McCann, L.; Fukai, T.; Holland, S.M.; Mitch, W.E.; Harrison, D.G. Oxidation of Tetrahydrobiopterin Leads to Uncoupling of Endothelial Cell Nitric Oxide Synthase in Hypertension. J. Clin. Invest., 2003, 111, 12011209. 
[12] Singh, R.B.; Mengi, S.A.; Xu, Y.-J.; Arneja, A.S.; Dhalla, N.S. Pathogenesis of Atherosclerosis: A Multifactorial Process. Exp. Clin. Cardiol., 2002, 7, 40-53.

[13] Singh, U.; Jialal, I. Oxidative Stress and Atherosclerosis. Pathophysiology, 2006, 13, 129-142.

[14] Carnevale, R.; Bartimoccia, S.; Nocella, C.; Di Santo, S.; Loffredo, L.; Illuminati, G.; Lombardi, E.; Boz, V.; Del Ben, M.; De Marco, L.; Pignatelli, P.; Violi, F. LDL Oxidation by Platelets Propagates Platelet Activation via an Oxidative Stress-Mediated Mechanism. Atherosclerosis, 2014, 237, 108-116.

[15] Judkins, C.P.; Diep, H.; Broughton, B.R.S.; Mast, A.E.; Hooker, E.U.; Miller, A.A.; Selemidis, S.; Dusting, G.J.; Sobey, C.G.; Drummond, G.R. Direct Evidence of a Role for Nox2 in Superoxide Production, Reduced Nitric Oxide Bioavailability, and Early Atherosclerotic Plaque Formation in ApoE-/- Mice. Am. J. Physiol. Heart Circ. Physiol., 2010, 298, H24-H32.

[16] Douglas, G.; Bendall, J.K.; Crabtree, M.J.; Tatham, A.L.; Carter, E.E.; Hale, A.B.; Channon, K.M. Endothelial-Specific Nox2 Overexpression Increases Vascular Superoxide and Macrophage Recruitment in ApoE ${ }^{-}{ }^{-}$Mice. Cardiovasc. Res., 2012, 94, 20-29.

[17] Guzik, T.J.; Sadowski, J.; Guzik, B.; Jopek, A.; Kapelak, B.; Przybylowski, P.; Wierzbicki, K.; Korbut, R.; Harrison, D.G.; Channon, K.M. Coronary Artery Superoxide Production and Nox Isoform Expression in Human Coronary Artery Disease. Arterioscler. Thromb. Vasc. Biol., 2005, 26, 333-339.

[18] Libby, P. Inflammation in Atherosclerosis. Arterioscler. Thromb. Vasc. Biol., 2012, 32, 2045-2051.

[19] Galkina, E.; Ley, K. Immune and Inflammatory Mechanisms of Atherosclerosis. Annu. Rev. Immunol., 2009, 27, 165-197.

[20] Linton, M.F.; Yancey, P.G.; Davies, S.S.; Jerome, W.G.; Linton, E.F.; Vickers, K.C. The Role of Lipids and Lipoproteins in Atherosclerosis. In: De Groot, L.J.; Chrousos, G.; Dungan, K., Feingold, K.R.; Grossman, A.; Hershman, J.M.; Koch, C.; Korbonits, M.; McLachlan, R.; New, M.; Purnell, J.; Rebar, R.; Singer, F.; Vinik, A. Editors. Endotext [Internet]. South Dartmouth (MA): MDText.com, Inc.; $\mathbf{2 0 0 0 .}$

[21] Covas, M.I.; Konstantinidou, V.; Fitó, M. Olive Oil and Cardiovascular Health. J. Cardiovasc. Pharmacol., 2009, 54, $477-$ 482 .

[22] Buckland, G.; Travier, N.; Barricarte, A; Ardanaz, E; MorenoIribas, C.; Sánchez, M.-J.; Molina-Montes, E.; Chirlaque, M. D.; Huerta, J. M.; Navarro, C.; Redondo, M. L.; Amiano, P.; Dorronsoro, M.; Larrañaga, N.; Gonzalez, C. A. Olive Oil Intake and CHD in the European Prospective Investigation into Cancer and Nutrition Spanish Cohort. Br. J. Nutr., 2012, 108, 2075-2082.

[23] Pacheco, Y.M.; López, S.; Bermúdez, B.; Abia, R.; Muriana, F.J.G. Extra-Virgin vs. Refined Olive Oil on Postprandial Hemostatic Markers in Healthy Subjects. J. Thromb. Haemost., 2006, 4, 1421 1422.

[24] Pacheco, Y.M.; Bermúdez, B.; López, S.; Abia, R.; Villar, J.; Muriana, F.J.G. Minor Compounds of Olive Oil Have Postprandial Anti-Inflammatory Effects. Br. J. Nutr., 2007, 98, 260-263.

[25] Ramirez-Tortosa, M.C.; Urbano, G.; López-Jurado, M.; Nestares, T.; Gomez, M.C.; Mir, A.; Ros, E.; Mataix, J.; Gil, A. Extra-Virgin Olive Oil Increases the Resistance of LDL to Oxidation More than Refined Olive Oil in Free-Living Men with Peripheral Vascular Disease. J. Nutr., 1999, 129, 2177-2183.

[26] Casas, R.; Urpi-Sardà, M.; Sacanella, E.; Arranz, S.; Corella, D.; Castañer, O.; Lamuela-Raventós, R.-M.; Salas-Salvadó, J.; Lapetra, J.; Portillo, M.P.; Estruch, R. Anti-Inflammatory Effects of the Mediterranean Diet in the Early and Late Stages of Atheroma Plaque Development. Mediators Inflamm., 2017, 2017, 3674390.

[27] Gerber, M.; Hoffman, R. The Mediterranean Diet: Health, Science and Society. Br. J. Nutr., 2015, S2, S4-S10.

[28] Tripoli, E.; Giammanco, M.; Tabacchi, G.; Di Majo, D.; Giammanco, S.; La Guardia, M. The Phenolic Compounds of Olive Oil: Structure, Biological Activity and Beneficial Effects on Human Health. Nutr. Res. Rev., 2005, 18, 98-112.

[29] Bogani, P.; Galli, C.; Villa, M.; Visioli, F. Postprandial AntiInflammatory and Antioxidant Effects of Extra Virgin Olive Oil. Atherosclerosis, 2007, 190, 181-186.

[30] Visioli, F.; Caruso, D.; Grande, S.; Bosisio, R.; Villa, M.; Galli, G.; Sirtori, C.; Galli, C. Virgin Olive Oil Study (VOLOS) Vasoprotective Potential of Extra Virgin Olive Oil in Mildly Dyslipidemic Patients. Eur. J. Nutr., 2005, 44, 121-127.
[31] Carnevale, R.; Pignatelli, P.; Nocella, C.; Loffredo, L.; Pastori, D Vicario, T.; Petruccioli, A.; Bartimoccia, S.; Violi, F. Extra Virgin Olive Oil Blunt Post-Prandial Oxidative Stress via NOX2 downRegulation. Atherosclerosis, 2014, 235, 649-658.

[32] Mitjavila, M.T.; Fandos, M.; Salas-Salvadó, J.; Covas, M.-I.; Borrego, S.; Estruch, R.; Lamuela-Raventós, R.; Corella, D.; Martínez-Gonzalez, M.Á.; Sánchez, J.M.; Bulló, M.; Fitó, M.; Tormos, C.; Cerdá, C.; Casillas, R.; Moreno, J.J.; Iradi, A.; Zaragoza, C.; Chaves, J.; Sáez, G.T. The mediterranean diet improves the systemic lipid and dna oxidative damage in metabolic syndrome individuals. A randomized, controlled, trial. Clin. Nutr., 2013, 32, 172-178.

[33] Kibel, A.; Selthofer-Relatic, K.; Drenjancevic, I.; Bacun, T. Bosnjak, I.; Kibel, D.; Gros, M. Coronary microvascular dysfunction in diabetes mellitus. J. Int. Med. Res., 2017 030006051667550 .

[34] Rallidis, L.S.; Kolomvotsou, A.; Lekakis, J.; Farajian, P.; Vamvakou, G.; Dagres, N.; Zolindaki, M.; Efstathiou, S.; Anastasiou-Nana, M.; Zampelas, A. Short-Term Effects of Mediterranean-Type Diet Intervention on Soluble Cellular Adhesion Molecules in Subjects with Abdominal Obesity. Clin. Nutr. ESPEN, 2017, 17, 38-43.

[35] Davis, C.R.; Hodgson, J.M.; Woodman, R.; Bryan, J.; Wilson, C.; Murphy, K.J. A mediterranean diet lowers blood pressure and improves endothelial function: results from the medley randomized intervention trial. Am. J. Clin. Nutr., 2017, 105, 1305-1313

[36] Sala-Vila, A.; Romero-Mamani, E.-S.; Gilabert, R.; Núñez, I.; de la Torre, R.; Corella, D.; Ruiz-Gutiérrez, V.; López-Sabater, M.-C.; Pintó, X.; Rekondo, J.; Martínez-González, M.-Á.; Estruch, R.; Ros, E. Changes in Ultrasound-Assessed Carotid Intima-Media Thickness and Plaque with a Mediterranean Diet: A Substudy of the PREDIMED Trial. Arterioscler. Thromb. Vasc. Biol., 2014, 34, 439-445.

[37] Storniolo, C.E.; Casillas, R.; Bulló, M.; Castañer, O.; Ros, E.; Sáez, G.T.; Toledo, E.; Estruch, R.; Ruiz-Gutiérrez, V.; Fitó, M.; Martínez-González, M.A.; Salas-Salvadó, J.; Mitjavila, M.T.; Moreno, J.J. A Mediterranean Diet Supplemented with Extra Virgin Olive Oil or Nuts Improves Endothelial Markers Involved in Blood Pressure Control in Hypertensive Women. Eur. J. Nutr., 2017, 56, 89-97.

[38] Medina-Remón, A.; Tresserra-Rimbau, A.; Pons, A.; Tur, J.A.; Martorell, M.; Ros, E.; Buil-Cosiales, P.; Sacanella, E.; Covas, M.I.; Corella, D.; Salas-Salvadó, J.; Gómez-Gracia, E.; RuizGutiérrez, V.; Ortega-Calvo, M.; García-Valdueza, M.; Arós, F.; Saez, G.T.; Serra-Majem, L.; Pinto, X.; Vinyoles, E.; Estruch, R.; Lamuela-Raventos, R. M.; PREDIMED Study Investigators. Effects of Total Dietary Polyphenols on Plasma Nitric Oxide and Blood Pressure in a High Cardiovascular Risk Cohort. The PREDIMED Randomized Trial. Nutr. Metab. Cardiovasc. Dis. 2015, 25, 60-67.

[39] Mitra, S.; Deshmukh, A.; Sachdeva, R.; Lu, J.; Mehta, J.L. Oxidized Low-Density Lipoprotein and Atherosclerosis Implications in Antioxidant Therapy. Am. J. Med. Sci., 2011, 342 , 135-142.

[40] Hernáez, Á.; Castañer, O.; Goday, A.; Ros, E.; Pintó, X.; Estruch, R.; Salas-Salvadó, J.; Corella, D.; Arós, F.; Serra-Majem, L.; Martínez-González, M.Á.; Fiol, M.; Lapetra, J.; de la Torre, R.; López-Sabater, M.C.; Fitó, M. The Mediterranean Diet Decreases LDL Atherogenicity in High Cardiovascular Risk Individuals: A Randomized Controlled Trial. Mol. Nutr. Food Res., 2017, 1601015.

[41] Fitó, M.; Estruch, R.; Salas-Salvadó, J.; Martínez-Gonzalez, M.A.; Arós, F.; Vila, J.; Corella, D.; Díaz, O.; Sáez, G.; de la Torre, R.; Mitjavila, M.-T.; Muñoz, M.A.; Lamuela-Raventós, R.-M.; RuizGutierrez, V.; Fiol, M.; Gómez-Gracia, E.; Lapetra, J.; Ros, E.; Serra-Majem, L.; Covas, M.-I.; PREDIMED Study Investigators. Effect of the Mediterranean Diet on Heart Failure Biomarkers: A Randomized Sample from the PREDIMED Trial. Eur. J. Heart Fail., 2014, 16, 543-550.

[42] Covas, M.-I.; Nyyssönen, K.; Poulsen, H.E.; Kaikkonen, J.; Zunft, H.-J. F.; Kiesewetter, H.; Gaddi, A.; de la Torre, R.; Mursu, J.; Bäumler, H.; Nascetti, S.; Salonen, J.T.; Fitó, M.; Virtanen, J.; Marrugat, J.; EUROLIVE Study Group. The Effect of Polyphenols in Olive Oil on Heart Disease Risk Factors: A Randomized Trial. Ann. Intern. Med., 2006, 145, 333-341. 
[43] Cicero, A.F.G.; Nascetti, S.; López-Sabater, M.C.; Elosua, R. Salonen, J.T.; Nyyssönen, K.; Poulsen, H.E.; Zunft, H.-J.F.; Kiesewetter, H.; de la Torre, K.; Covas, M.-I.; Kaikkonen, J.; Mursu, J.; Koenbick, C.; Bäumler, H.; Gaddi, A.V. EUROLIVE Study Group. Changes in LDL Fatty Acid Composition as a Response to Olive Oil Treatment Are Inversely Related to Lipid Oxidative Damage: The EUROLIVE Study. J. Am. Coll. Nutr., 2008, 27, 314-320.

[44] Castañer, O.; Fitó, M.; López-Sabater, M.C.; Poulsen, H.E.; Nyyssönen, K.; Schröder, H.; Salonen, J.T.; De la Torre-Carbot, K.; Zunft, H.-F.; De la Torre, R.; Bäumler, H.; Gaddi, A.V.; Saez, G.T.; Tomás, M.; Covas, M.-I.; EUROLIVE Study Group. The Effect of Olive Oil Polyphenols on Antibodies against Oxidized LDL. A Randomized Clinical Trial. Clin. Nutr., 2011, 30, 490-493.

[45] Castaner, O.; Covas, M.-I.; Khymenets, O.; Nyyssonen, K.; Konstantinidou, V.; Zunft, H.-F.; de la Torre, R.; Munoz-Aguayo, D.; Vila, J.; Fito, M. Protection of LDL from Oxidation by Olive Oil Polyphenols Is Associated with a Downregulation of CD40Ligand Expression and Its Downstream Products in vivo in Humans. Am. J. Clin. Nutr., 2012, 95, 1238-1244.

[46] Casas, R.; Sacanella, E.; Urpí-Sardà, M.; Chiva-Blanch, G.; Ros, E.; Martínez-González, M.-A.; Covas, M.-I.; Rosa Ma LamuelaRaventos, J.; Salas-Salvadó, J.; Fiol, M.; Arós, F.; Estruch, R. The Effects of the Mediterranean Diet on Biomarkers of Vascular Wall Inflammation and Plaque Vulnerability in Subjects with High Risk for Cardiovascular Disease. A Randomized Trial. PLoS One, 2014, 9, e100084.

[47] Casas, R.; Sacanella, E.; Urpí-Sardà, M.; Corella, D.; Castañer, O.; Lamuela-Raventos, R.-M.; Salas-Salvadó, J.; Martínez-González, M.-A.; Ros, E.; Estruch, R. Long-Term Immunomodulatory Effects of a Mediterranean Diet in Adults at High Risk of Cardiovascular Disease in the PREvención Con DIeta MEDiterránea (PREDIMED) Randomized Controlled Trial. J. Nutr., 2016, 146, 1684-1693.

[48] Esposito, K.; Marfella, R.; Ciotola, M.; Di Palo, C.; Giugliano, F.; Giugliano, G.; D’Armiento, M.; D’Andrea, F.; Giugliano, D. Effect of a Mediterranean-Style Diet on Endothelial Dysfunction and Markers of Vascular Inflammation in the Metabolic Syndrome: A Randomized Trial. JAMA, 2004, 292, 1440-1446.

[49] Babio, N.; Toledo, E. Estruch, R; Ros, E; Martínez-González, M.A.; Castañer, O.; Bulló, M.; Corella, D.; Arós, F.; GómezGracia, E.; Ruiz-Gutiérrez, V.; Fiol, M.; Lapetra, J.; LamuelaRaventos, R.M.; Serra-Majem, L.; Pintó, X.; Basora, J.; Sorlí, J.V.; Salas-Salvadó, J.; PREDIMED Study Investigators. Mediterranean diets and metabolic syndrome status in the PREDIMED randomized trial. CMAJ, 2014, 186, E649- E657.

[50] Cherki, M.; Derouiche, A.; Drissi, A.; El Messal, M.; Bamou, Y.; Idrissi-Ouadghiri, A.; Khalil, A.; Adlouni, A. Consumption of argan oil may have an antiatherogenic effect by improving paraoxonase activities and antioxidant status: Intervention study in healthy men. Nutr. Metab. Cardiovasc. Dis., 2005, 15, 352-360.

[51] Estruch, R.; Martínez-González, M.A.; Corella, D.; Salas-Salvadó, J.; Fitó, M.; Chiva-Blanch, G.; Fiol, M.; Gómez-Gracia, E.; Arós, F.; Lapetra, J.;Serra-Majem, L.; Pintó, X.; Buil-Cosiales, P.; Sorlí, J.V.; Muñoz, M.A.; Basora-Gallisá, J.; Lamuela-Raventós, R.M.; Serra-Mir, M.; Ros, E.; PREDIMED Study Investigators. Effect of a high-fat Mediterranean diet on bodyweight and waist circumference: a prespecified secondary outcomes analysis of the PREDIMED randomised controlled trial. Lancet Diabetes Endocrinol., 2016, 4, 666-676.

[52] Farnetti, S.; Malandrino, N.; Luciani, D.; Gasbarrini, G.; Capristo, E. Food fried in extra-virgin olive oil improves postprandial insulin response in obese, insulin-resistant women. J. Med. Food., 2011, 14, 316-321.

[53] Hernáez, Á.; Castañer, O.; Elosua, R.; Pintó, X.; Estruch, R.; SalasSalvadó, J.; Corella, D.; Arós, F.; Serra-Majem, L.; Fiol, M.; Ortega-Calvo, M.; Ros, E.; Martínez-González, M.Á.; de la Torre, R.; López-Sabater, M.C.; Fitó, M. Mediterranean Diet Improves HighDensity Lipoprotein Function in High-Cardiovascular-Risk Individuals: A Randomized Controlled Trial. Circulation, 2017, 135, 633-643.
[54] Maki, K.C.; Lawless, A.L.; Kelley, K.M.; Kaden, V.N.; Geiger, C.J.; Palacios, O.M.; Dicklin, M.R. Corn Oil Intake Favorably Impacts Lipoprotein Cholesterol, Apolipoprotein and Lipoprotein Particle Levels Compared with Extra-Virgin Olive Oil. Eur. J. Clin. Nutr., 2017, 71, 33-38.

[55] Rodríguez-Rejón, A.I.; Castro-Quezada, I.; Ruano-Rodríguez, C; Ruiz-López, M.D.; Sánchez-Villegas, A.; Toledo, E.; Artacho, R. Estruch, R.; Salas-Salvadó, J.; Covas, M.I.; Corella, D.; GómezGracia, E.; Lapetra, J.; Pintó, X.; Arós, F.; Fiol, M.; LamuelaRaventós, R.M; Ruiz-Gutierrez, V.; Schröder, H; Ros, E. Martínez-González, M.Á.; Serra-Majem, L. Effect of a Mediterranean Diet Intervention on Dietary Glycemic Load and Dietary Glycemic Index: The PREDIMED Study. J. Nutr. Metab., 2014, 2014, 985373

[56] Toledo, E.; Hu, F.B.; Estruch, R.; Buil-Cosiales, P.; Corella, D.; Salas-Salvadó, J.; Covas, M.I.; Arós, F.; Gómez-Gracia, E.; Fiol, M.; Lapetra, J.; Serra-Majem, L.; Pinto, X.; Lamuela-Raventós, R.M.; Saez, G.; Bulló, M.; Ruiz-Gutiérrez, V.; Ros, E.; Sorli, J.V.; Martinez-Gonzalez, M.A. Effect of the Mediterranean diet on blood pressure in the PREDIMED trial: results from a randomized controlled trial. BMC Med., 2013, 11, 207.

[57] Violi, F.; Loffredo, L.; Pignatelli, P.; Angelico, F.; Bartimoccia, S Nocella, C.; Cangemi, R.; Petruccioli, A.; Monticolo, R.; Pastori, D.; Carnevale, R. Extra Virgin Olive Oil Use Is Associated with Improved Post-Prandial Blood Glucose and LDL Cholesterol in Healthy Subjects. Nutr. Diabetes., 2015, 5, e172.

[58] Yu, E.; Ruiz-Canela, M.; Guasch-Ferré, M.; Zheng, Y.; Toledo, E.; Clish, C.B.; Salas-Salvadó, J.; Liang, L.; Wang, D.D.; Corella, D.; Fitó, M.; Gómez-Gracia, E.; Lapetra, J.; Estruch, R.; Ros, E.; Cofán, M.; Arós, F.; Romaguera, D.; Serra-Majem, L.; Sorlí, J.V.; Hu, F.B.; Martinez-Gonzalez, M.A. Increases in Plasma Tryptophan Are Inversely Associated with Incident Cardiovascular Disease in the Prevención con Dieta Mediterránea (PREDIMED) Study. J. Nutr., 2017, 147, 314-322.

[59] Hollander, W. Role of Hypertension in Atherosclerosis and Cardiovascular Disease. Am. J. Cardiol., 1976, 38, 786-800.

[60] Choy, P.C.; Siow, Y.L.; Mymin, D.; OK. Lipids and Atherosclerosis. Biochem. Cell Biol., 2004, 82, 212-224.

[61] Selvin, E.; Coresh, J.; Golden, S.H.; Boland, L.L.; Brancati, F.L.; Steffes, M.W.; Atherosclerosis risk in communities study. Glycemic Control, Atherosclerosis, and Risk Factors for Cardiovascular Disease in Individuals with Diabetes: The Atherosclerosis Risk in Communities Study. Diabetes Care, 2005, 28, 1965-1973.

[62] Carnevale, R.; Loffredo, L.; Del Ben, M.; Angelico, F.; Nocella, C.; Petruccioli, A.; Bartimoccia, S.; Monticolo, R.; Cava, E.; Violi, F. Extra Virgin Olive Oil Improves Post-Prandial Glycemic and Lipid Profile in Patients with Impaired Fasting Glucose. Clin Nutr., 2017, 36, 782-787.

[63] Reiner, Z.; Catapano, A.L.; De Backer, G.; Graham, I.; Taskinen, M.-R.; Wiklund, O.; Agewall, S.; Alegria, E.; Chapman, M.J.; Durrington, P.; Erdine, S.; Halcox, J.; Hobbs, R.; Kjekshus, J.; Filardi, P.P.; Riccardi, G.; Storey, R.F.; Wood, D.; Bax, J.; Vahanian, A.; Auricchio, A.; Baumgartner, H.; Ceconi, C.; Dean, V.; Deaton, C.; Fagard, R.; Filippatos, G.; Funck-Brentano, C.; Hasdai, D.; Hobbs, R.; Hoes, A.; Kearney, P.; Knuuti, J.; Kolh, P.; McDonagh, T.; Moulin, C.; Poldermans, D.; Popescu, B.A.; Reiner, Z.; Sechtem, U.; Sirnes, P.A.; Tendera, M.; Torbicki, A.; Vardas, P.; Widimsky, P.; Windecker, S.; Reviewers:, D.; Funck-Brentano, C.; Poldermans, D.; Berkenboom, G.; De Graaf, J.; Descamps, O.; Gotcheva, N.; Griffith, K.; Guida, G.F.; Gulec, S.; Henkin, Y.; Huber, K.; Kesaniemi, Y.A.; Lekakis, J.; Manolis, A.J.; MarquesVidal, P.; Masana, L.; McMurray, J.; Mendes, M.; Pagava, Z.; Pedersen, T.; Prescott, E.; Rato, Q.; Rosano, G.; Sans, S.; Stalenhoef, A.; Tokgozoglu, L.; Viigimaa, M.; Wittekoek, M.E.; Zamorano, J.L. ESC/EAS Guidelines for the Management of Dyslipidaemias: The Task Force for the Management of Dyslipidaemias of the European Society of Cardiology (ESC) and the European Atherosclerosis Society (EAS). Eur. Heart J., 2011, $32,1769-1818$ 